\title{
VARIATION IN THE DIURETIC RESPONSE TO INGESTED WATER RELATED TO THE RENAL EXCRETION OF SOLUTES ${ }^{1}$
}

\author{
By JACK D. ROSENBAUM, WILLIAM P. NELSON, III, MAURICE B. STRAUSS, \\ ROBERT K. DAVIS, AND ELSIE C. ROSSMEISL \\ (From the Medical Service and Research Laboratory, Cushing Veterans Administration Hospital, \\ Framingham, Mass. [Present address-V. A. Hospital, Boston, Mass.])
}

(Submitted for publication September 9, 1952; accepted January 21, 1953)

The administration of a large amount of water to the normal subject results in the copious excretion of a dilute urine. An extensive body of evidence indicates that this response is primarily dependent upon a decrease in the effective osmotic pressure of the plasma and extracellular fluid, with resultant inhibition of the secretion of antidiuretic hormone $(\mathrm{ADH})$ by the neurohypophysis and decreased facultative reabsorption of water by the renal tubules $(2-5)$.

Although alterations of this normal response to water loading have been studied in a variety of abnormal conditions, factors which influence the magnitude of water diuresis in normal man have received scant attention, even though Haldane and Priestley in 1916 noted that the initial high rates of urine flow which followed the ingestion of water subsequently underwent a gradual moderate decline despite a continued large fluid intake (6). Depletion of body sodium in man and experimental animals has been shown to diminish the excretion of administered water, but under the conditions of these studies general impairment of renal excretory function was evident (7-9) or was not excluded $(10,11)$.

The present communication describes observations which indicate that in man the maintenance of a large water load evokes a diuresis the magnitude of which is greatly influenced by factors which evoke concomitant changes in the renal excretion of solutes, particularly sodium. These influences include the dietary intake of sodium, postural effects, and the administration of various solute loads.

\section{METHODS}

The subjects were three normal men and seven adult male patients, of whom four had neurodermititis, one psoriasis, one bronchial asthma, and one rheumatoid ar-

1 A preliminary report (1) was presented at the Fortysecond Annual Meeting of the American Society for Clinical Investigation, Atlantic City, N. J., May 1, 1950. thritis. All were free of renal or cardiovascular disease. Dietary intake was controlled only with regard to its sodium content. The regimens employed were: 1) "saltfree" diet providing approximately $15 \mathrm{mEq}$. of sodium daily ; 2) "salt-poor" diet providing $35-70 \mathrm{mEq}$. of sodium daily ; 3) "regular" diet of unrestricted salt content containing approximately $170-250 \mathrm{mEq}$. of sodium; 4) "high-salt" diet consisting of the "regular" diet with $170 \mathrm{mEq}$. of added sodium chloride. The same regimen was employed for a minimum of three days before each experiment, except that the "high-salt" diet was given for only one day prior to an experiment in subjects who had previously been taking the regular diet. Repeated studies were performed on the same subjects at intervals which ranged from one week to 10 months. Hence weight changes unrelated to dietary salt intake occurred.

The subjects came to the laboratory one to two hours after breakfast, voided, and were weighed on a scale sensitive to $\pm 10 \mathrm{gm}$. Arterialized venous blood (12) was then obtained and a water load established by the ingestion of tap water at room temperature. In most experiments, $1500 \mathrm{ml}$. were drunk during a period of 10 to 40 minutes. The subject was again weighed and the water load was maintained throughout the experiment by oral administration of enough water after each voiding to restore body weight to its previous value. ${ }^{2}$ In two experiments (A-1 and B-1) a larger water load of $3000 \mathrm{ml}$. was established more gradually over a period of several hours and was subsequently allowed to decrease to 1800

2 It is recognized that with this technique there occurs a small cumulative increase in total body water, since no allowance is made for water gained by oxidation of protein, fat or carbohydrate. Furthermore, each decrement of weight on which replacement of water is based represents not only insensible water loss and water of urine and blood samples, but also the solids lost in the urine voided, the blood samples taken, and loss of weight incident to the oxidative metabolism by respiratory gas exchange. However, in experiments the duration of which never exceeded 10 hours this increase in the water load initially established is unimportant, since our own observations as well as those of Adolph (13) indicate that in man the diuretic responses to water loads ranging from 1500 to $3000 \mathrm{ml}$. are essentially the same. Moreover, we have found that administration of an additional liter of water after a load of $1500 \mathrm{ml}$. has been maintained for six hours has no apparent influence on the course of the diuretic response. 
WATER DIURESIS AND SOLUTE EXCRETION

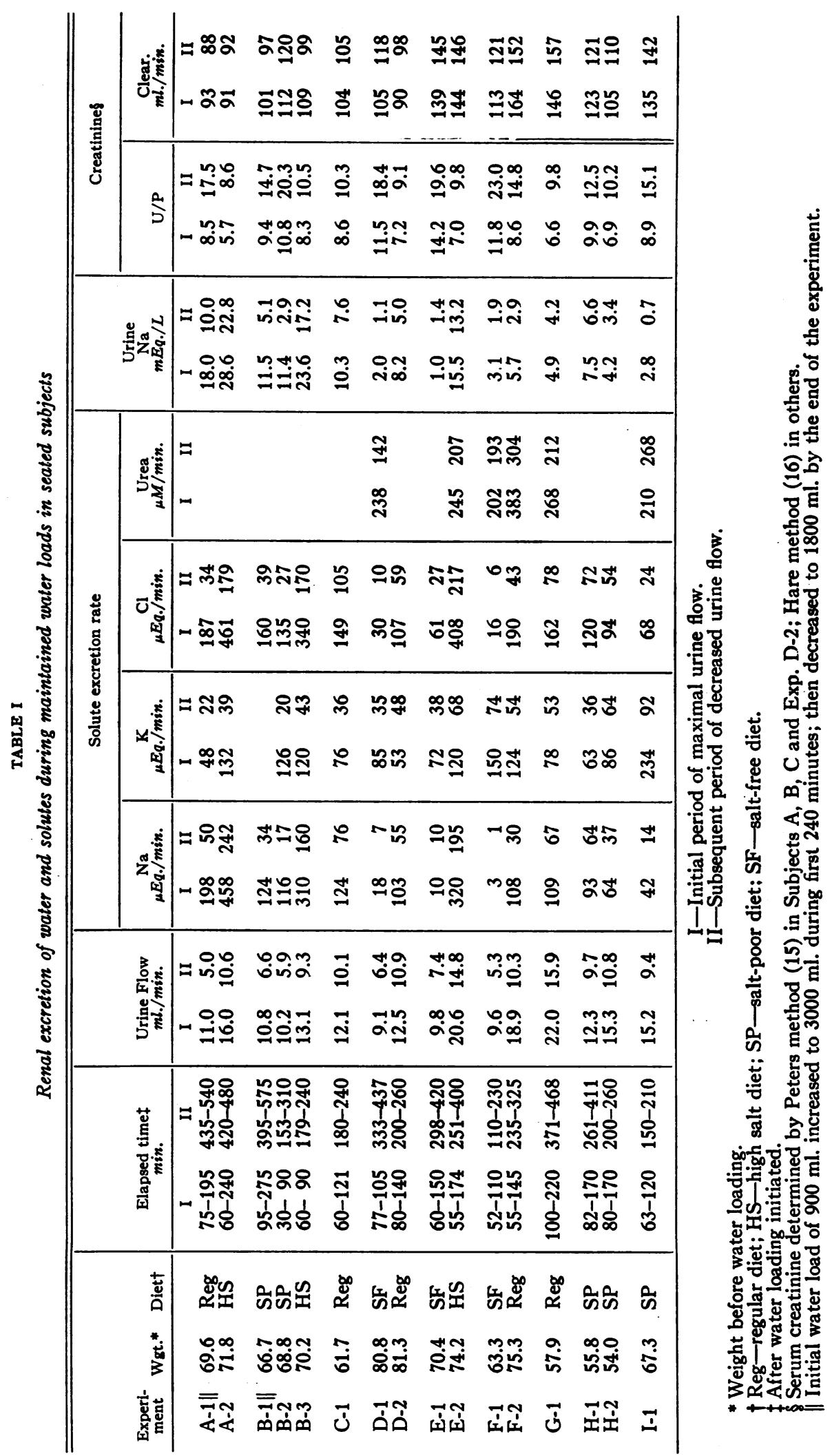


ml. Except in experiments designed to study the influence of postural change, the subjects remained seated in a straight-backed chair, standing up only to void and to be weighed at intervals of approximately 30 minutes. Smoking was not permitted except in the case of Subject $A$, an inveterate pipe smoker, who did not inhale and who had repeatedly demonstrated that his diuretic response to ingested water was not influenced by smoking. Additional arterialized blood was obtained at intervals of one to four hours during the course of each experiment. Determinations were made of total protein, sodium, potassium, chloride, $\mathrm{CO}_{2}$ content, creatinine, and urea in serum, as well as of hemoglobin and hematocrit. In urine, sodium, potassium, chloride, creatinine, urea, and ammonia were measured. The methods employed have been described previously (14), except that in some experiments serum creatinine was determined by the method of Peters (15) instead of that of Hare (16). Our experience confirms the finding of Hare that her procedure gives serum creatinine values in normal subjects approximately 0.2 mgm. per cent below those obtained by the techniques which measure total creatinine-like chromogen. There is good agreement between values for creatinine in urine as determined by the two methods. Therefore endogenous creatinine clearances in normal subjects based on serum values determined by the method of Peters are usually about 20 per cent lower than those based on values obtained by the Hare procedure.

\section{RESULTS}

\section{A. Response to maintained water loads}

The renal excretion of water and electrolyte during maintained water loads with the subjects seated is indicated in Table I. Initial rates of urine flow in the nine subjects ranged from 9.1 to $22.0 \mathrm{ml}$. per minute, but when the same subject was repeatedly studied while taking a relatively constant diet, the initial diuretic response was much less variable. In each of these 16 experiments the initial maximal rate of urine flow subsequently declined during the course of the experiment, although the magnitude of the water load was unchanged or actually greater at this time. Since endogenous creatinine clearance remained relatively constant, changes in flow were presumed to depend upon increased tubular reabsorption of water, also indicated by the rise in creatinine $U / P$ ratio which took place during the course of each experiment of this group.

Initial rates of sodium excretion varied over a very wide range, consistent with the large differences in antecedent dietary sodium intake. Except when this initial excretory rate was extremely low, a large, steady decline in natriuresis was observed during the course of each experiment. This decline in excretion of sodium was relatively larger than that in water, so that concentration of sodium in the urine characteristically fell during the experimental period. Changes in chloride excretion rates and concentration were generally similar to those observed for sodium. Potassium excretion also fell strikingly in all but one instance. However, whereas excretion of water, sodium and chloride characteristically decreased steadily throughout the experiment, potassium output usually declined rapidly in the first several hours and then remained at a relatively constant level. Urea excretion, when measured, usually underwent a moderate decrease, which, similarly to potassium, often took place only in the first hours after water loading.

The regular occurrence of hemodilution both during the initial periods of maximal flow and

TABLE II

Alteration in renal excretion of water and solutes with change in posture

\begin{tabular}{|c|c|c|c|c|c|c|c|c|c|c|c|c|c|c|c|c|c|c|c|}
\hline \multirow{3}{*}{$\begin{array}{c}\text { Experi- } \\
\text { ment }\end{array}$} & \multirow{3}{*}{ Diet* } & \multirow{2}{*}{\multicolumn{2}{|c|}{$\begin{array}{c}\text { Elapeed time + } \\
\text { min. }\end{array}$}} & \multirow{2}{*}{\multicolumn{2}{|c|}{$\begin{array}{l}\text { Urine flow } \\
\text { ml. } / \text { min. }\end{array}$}} & \multirow{2}{*}{\multicolumn{2}{|c|}{$\stackrel{\mathrm{Na}}{\mu E_{q .} / \text { min. }}$}} & \multirow{2}{*}{\multicolumn{2}{|c|}{$\underset{\mu E q . / \min }{\mathbf{K}}$}} & \multirow{2}{*}{\multicolumn{2}{|c|}{$\underset{\mu E q . / \min }{\mathrm{Cl}}$}} & \multirow{2}{*}{\multicolumn{2}{|c|}{$\begin{array}{c}\text { Urea } \\
\mu M / m i n .\end{array}$}} & \multirow{2}{*}{\multicolumn{2}{|c|}{$\underset{m E q . / L}{\text { Urine } \mathrm{Na}}$}} & \multicolumn{4}{|c|}{ Creatinine } \\
\hline & & & & & & & & & & & & & & & & \multicolumn{2}{|c|}{$\mathbf{U} / \mathbf{P}$} & \multicolumn{2}{|c|}{ Clear. } \\
\hline & & $\mathbf{S}$ & $\mathbf{R}$ & $\mathbf{s}$ & $\mathbf{R}$ & $\mathbf{s}$ & $\mathbf{R}$ & $\mathbf{s}$ & $\mathbf{R}$ & $\mathbf{s}$ & $\mathbf{R}$ & $\mathbf{s}$ & $\mathbf{R}$ & $\mathbf{S}$ & $\mathbf{R}$ & $\mathbf{s}$ & $\mathbf{R}$ & $\mathbf{s}$ & $\mathbf{R}$ \\
\hline $\begin{array}{l}\text { D-1 } \\
\text { D-3 } \\
\text { E-2 } \\
\text { F-2 } \\
\text { G-1 }\end{array}$ & $\begin{array}{l}\text { SF } \\
\text { Reg } \\
\text { HS } \\
\text { HS } \\
\text { Reg }\end{array}$ & $\begin{array}{l}333-437 \\
125-260 \\
251-370 \\
235-325 \\
371-468\end{array}$ & $\mid \begin{array}{l}437-495 \\
320-440 \\
370-520 \\
355-415 \\
530-559\end{array}$ & $\begin{array}{r}6.4 \\
11.3 \\
15.3 \\
10.3 \\
15.9\end{array}$ & $\begin{array}{r}9.3 \\
13.5 \\
13.3 \\
16.3 \\
19.7\end{array}$ & $\begin{array}{r}7 \\
69 \\
209 \\
30 \\
67\end{array}$ & $\begin{array}{r}24 \\
115 \\
146 \\
195 \\
93\end{array}$ & $\begin{array}{l}35 \\
49 \\
72 \\
54 \\
53\end{array}$ & $\begin{array}{l}34 \\
28 \\
52 \\
69 \\
49\end{array}$ & $\begin{array}{r}10 \\
105 \\
235 \\
43 \\
78\end{array}$ & $\begin{array}{r}14 \\
109 \\
170 \\
95 \\
87\end{array}$ & $\begin{array}{l}192 \\
154 \\
197 \\
304 \\
212\end{array}$ & $\begin{array}{l}209 \\
183 \\
178 \\
290 \\
229\end{array}$ & $\begin{array}{r}1.1 \\
6.1 \\
13.6 \\
2.9 \\
4.2\end{array}$ & $\begin{array}{r}2.6 \\
8.5 \\
11.0 \\
12.0 \\
4.7\end{array}$ & $\begin{array}{r}18.4 \\
10.2 \\
9.6 \\
14.8 \\
9.6\end{array}$ & $\begin{array}{r}13.3 \\
9.1 \\
11.5 \\
9.8 \\
7.9\end{array}$ & $\begin{array}{l}118 \\
115 \\
147 \\
152 \\
157\end{array}$ & $\begin{array}{l}124 \\
123 \\
153 \\
160 \\
155\end{array}$ \\
\hline
\end{tabular}

S-Seated.

R-Recumbent.

* SF - salt-free diet; Reg - regular diet; HS-high salt diet.

+ After water loading initiated. 
WATER DIURESIS AND SOLUTE EXCRETION

TABLE III

Renal excretion of water and solutes before and after ingestion of various solutes during maintained water loads

\begin{tabular}{|c|c|c|c|c|c|c|c|c|c|c|c|c|}
\hline Experiment & Period & $\begin{array}{c}\text { Elapsed } \\
\text { time* }\end{array}$ & $\begin{array}{l}\text { Ingested } \\
\text { solutet }\end{array}$ & $\begin{array}{l}\text { Urine } \\
\text { flow }\end{array}$ & $\mathrm{Na}$ & $\mathbf{K}_{\mathbf{K}}^{\text {Solv }}$ & e excretio & $\begin{array}{l}\text { rate } \\
\text { Urea }\end{array}$ & NH, & $\begin{array}{c}\text { Urine } \\
\mathrm{Na}\end{array}$ & $\begin{array}{c}\text { Crea } \\
\text { U/P }\end{array}$ & $\begin{array}{l}\text { tininet } \\
\text { Clear. }\end{array}$ \\
\hline $\begin{array}{l}\mathrm{C}-1 \\
61.7 \mathrm{Kg} .8 \\
\mathrm{NaHCO}\end{array}$ & $\underset{\text { VI }}{\text { III }_{\text {II }}^{I}}$ & $\begin{array}{c}\text { min. } \\
60-180 \\
180-240 \\
240-270 \\
270-300 \\
300-360 \\
360-440\end{array}$ & $\begin{array}{r}m M \\
0 \\
0 \\
72 \\
48 \\
48 \\
48\end{array}$ & $\begin{array}{r}\text { ml./min. } \\
11.7 \\
10.0 \\
8.8 \\
9.2 \\
11.3 \\
10.6\end{array}$ & $\begin{array}{r}\text { Eq. } \\
\text { min. } \\
111 \\
76 \\
53 \\
89 \\
208 \\
223\end{array}$ & $\begin{array}{c}\boldsymbol{\mu E q . /} \\
\text { min. } \\
61 \\
36 \\
32 \\
31 \\
85 \\
100\end{array}$ & $\begin{array}{c}\mu E q . / \\
\text { min. } \\
126 \\
66 \\
40 \\
17 \\
14 \\
9\end{array}$ & $\begin{array}{l}\mu M / \\
\text { mix. }\end{array}$ & $\begin{array}{l}\mu E_{\ell . /} \\
\text { mix. }\end{array}$ & $\begin{array}{c}m E q . / L \\
9.5 \\
7.6 \\
6.0 \\
9.7 \\
18.4 \\
21.0\end{array}$ & $\begin{array}{r}9.1 \\
10.4 \\
12.5 \\
11.3 \\
9.7 \\
9.8\end{array}$ & $\begin{array}{c}\text { ml./min. } \\
106 \\
104 \\
110 \\
104 \\
109 \\
104\end{array}$ \\
\hline $\begin{array}{l}\mathrm{D}-4 \\
80.4 \mathrm{Kg} . \\
\mathrm{KCl}\end{array}$ & II & $\begin{array}{r}90-270 \\
270-330 \\
330-420\end{array}$ & $\begin{array}{r}0 \\
94 \\
27\end{array}$ & $\begin{array}{l}7.9 \\
11.6 \\
11.9\end{array}$ & $\begin{array}{r}23 \\
64 \\
219\end{array}$ & $\begin{array}{r}37 \\
72 \\
286\end{array}$ & $\begin{array}{r}34 \\
73 \\
388\end{array}$ & & & $\begin{array}{r}2.9 \\
5.5 \\
18.4\end{array}$ & $\begin{array}{r}11.4 \\
8.4 \\
7.7\end{array}$ & $\begin{array}{l}90 \\
97 \\
92\end{array}$ \\
\hline $\begin{array}{l}\mathrm{D}-2 \\
81.3 \mathrm{Kg} \\
\mathrm{NH}, \mathrm{Cl}\end{array}$ & II & $\begin{array}{l}200-260 \\
260-410 \\
410-500\end{array}$ & $\begin{array}{r}0 \\
187 \\
37\end{array}$ & $\begin{array}{l}10.9 \\
12.0 \\
13.6\end{array}$ & $\begin{array}{r}55 \\
74 \\
120\end{array}$ & $\begin{array}{l}48 \\
37 \\
27\end{array}$ & $\begin{array}{r}59 \\
75 \\
140\end{array}$ & & & $\begin{array}{l}5.0 \\
6.2 \\
8.8\end{array}$ & $\begin{array}{l}9.0 \\
9.0 \\
8.1\end{array}$ & $\begin{array}{r}98 \\
108 \\
110\end{array}$ \\
\hline $\begin{array}{l}\mathrm{I}-1 \\
67.3 \mathrm{Kg} \\
\mathrm{NH}_{4} \mathrm{Cl}\end{array}$ & $\operatorname{IIII}_{\mathbf{I V}}^{I}$ & $\begin{array}{r}63-150 \\
150-210 \\
210-270 \\
270-420 \\
420-480\end{array}$ & $\begin{array}{r}0 \\
37 \\
112 \\
94 \\
0\end{array}$ & $\begin{array}{c}14.1 \\
9.4 \\
7.5 \\
4.6 \| \\
12.8\end{array}$ & $\begin{array}{r}35 \\
14 \\
6 \\
5 \\
47\end{array}$ & $\begin{array}{r}206 \\
92 \\
20 \\
26 \\
66\end{array}$ & $\begin{array}{r}187 \\
24 \\
27 \\
58 \\
126\end{array}$ & $\begin{array}{l}299 \\
268 \\
255 \\
286 \\
390\end{array}$ & $\begin{array}{l}13 \\
18 \\
55 \\
78 \\
66\end{array}$ & $\begin{array}{l}2.5 \\
1.5 \\
0.8 \\
1.1 \\
3.7\end{array}$ & $\begin{array}{r}9.4 \\
15.1 \\
16.5 \\
30.5 \\
12.1\end{array}$ & $\begin{array}{l}133 \\
142 \\
124 \\
140 \\
155\end{array}$ \\
\hline $\begin{array}{l}\text { B-7 } \\
69.0 \mathrm{Kg} . \\
\text { Urea }\end{array}$ & $\underset{\text { IV II }}{\text { II }}$ & $\begin{array}{c}32-88 \\
88-148 \\
148-208 \\
208-268 \\
268-358\end{array}$ & $\begin{array}{r}0 \\
166 \\
333 \\
250 \\
0\end{array}$ & $\begin{array}{r}8.9 \\
7.9 \\
8.9 \\
11.4 \\
11.8\end{array}$ & $\begin{array}{l}53 \\
30 \\
39 \\
54 \\
70\end{array}$ & $\begin{array}{r}114 \\
61 \\
43 \\
31 \\
37\end{array}$ & $\begin{array}{r}116 \\
64 \\
63 \\
75 \\
75\end{array}$ & $\begin{array}{r}294 \\
268 \\
774 \\
1343 \\
1196\end{array}$ & & $\begin{array}{l}5.9 \\
3.8 \\
4.4 \\
4.7 \\
5.9\end{array}$ & $\begin{array}{r}10.3 \\
12.2 \\
10.8 \\
8.8 \\
8.1\end{array}$ & $\begin{array}{r}92 \\
96 \\
96 \\
100 \\
96\end{array}$ \\
\hline $\begin{array}{l}\text { I-2 } \\
66.9 \mathrm{Kg} . \\
\text { Urea }\end{array}$ & $\underset{\text { III }}{\text { II }}$ & $\begin{array}{r}50-146 \\
146-200 \\
200-262 \\
262-320 \\
320-385\end{array}$ & $\begin{array}{r}0 \\
333 \\
333 \\
0 \\
0\end{array}$ & $\begin{array}{r}8.2 \\
8.1 \\
11.1 \\
8.3 \\
6.9\end{array}$ & $\begin{array}{l}5 \\
4 \\
8 \\
4 \\
3\end{array}$ & $\begin{array}{r}141 \\
101 \\
77 \\
44 \\
45\end{array}$ & $\begin{array}{l}25 \\
18 \\
30 \\
24 \\
19\end{array}$ & $\begin{array}{r}308 \\
396 \\
1195 \\
1054 \\
949\end{array}$ & $\begin{array}{r}9 \\
13 \\
24 \\
35 \\
32\end{array}$ & $\begin{array}{l}0.6 \\
0.5 \\
0.7 \\
0.5 \\
0.4\end{array}$ & $\begin{array}{l}15.1 \\
15.4 \\
10.2 \\
14.4 \\
16.2\end{array}$ & $\begin{array}{l}124 \\
125 \\
113 \\
119 \\
112\end{array}$ \\
\hline $\begin{array}{l}\text { J-1 } \\
72.0 \mathrm{Kg} . \\
\text { Urea }\end{array}$ & $\underset{\text { III }}{\text { II }}$ & $\begin{array}{r}85-123 \\
123-161 \\
161-214 \\
214-268 \\
268-325 \\
325-377\end{array}$ & $\begin{array}{r}0 \\
0 \\
333 \\
333 \\
0 \\
0\end{array}$ & $\begin{array}{l}16.3 \\
15.1 \\
13.6 \\
18.8 \\
17.5 \\
16.1\end{array}$ & $\begin{array}{l}147 \\
124 \\
124 \\
.232 \\
252 \\
235\end{array}$ & $\begin{array}{r}115 \\
119 \\
114 \\
110 \\
88 \\
112\end{array}$ & $\begin{array}{l}231 \\
245 \\
236 \\
347 \\
340 \\
323\end{array}$ & $\begin{array}{r}293 \\
276 \\
378 \\
1311 \\
1135 \\
986\end{array}$ & & $\begin{array}{r}9.0 \\
8.2 \\
9.1 \\
12.3 \\
14.4 \\
14.6\end{array}$ & $\begin{array}{r}9.8 \\
10.0 \\
12.1 \\
8.1 \\
8.3 \\
8.8\end{array}$ & $\begin{array}{l}160 \\
151 \\
164 \\
152 \\
146 \\
142\end{array}$ \\
\hline $\begin{array}{l}\mathrm{J}-2 \\
74.7 \mathrm{Kg} . \\
\text { Urea }\end{array}$ & $\underset{\text { III }}{\text { II }}$ & $\begin{array}{l}139-184 \\
184-239 \\
239-270 \\
270-327 \\
327-414\end{array}$ & $\begin{array}{r}0 \\
0 \\
333 \\
333 \\
0\end{array}$ & $\begin{array}{r}15.2 \\
11.5 \\
7.4 \\
11.1 \\
9.3\end{array}$ & $\begin{array}{r}61 \\
44 \\
11 \\
36 \\
1\end{array}$ & $\begin{array}{r}161 \\
80 \\
39 \\
55 \\
53\end{array}$ & $\begin{array}{l}91 \\
53 \\
20 \\
62 \\
42\end{array}$ & $\begin{array}{r}375 \\
326 \\
293 \\
1012 \\
910\end{array}$ & & $\begin{array}{l}4.0 \\
3.8 \\
1.3 \\
3.3 \\
1.1\end{array}$ & $\begin{array}{r}9.9 \\
11.7 \\
17.0 \\
11.9 \\
13.7\end{array}$ & $\begin{array}{l}150 \\
135 \\
126 \\
132 \\
127\end{array}$ \\
\hline
\end{tabular}

* After water loading initiated.

+ Solute listed in first column.

¥ Serum creatinine determined by Peters method (15) in Subjects B, C, and D; by Hare method (16) in others.

during the subsequent periods of reduced flow was indicated by a decline in hematocrit, hemoglobin and serum total protein concentrations. Concentrations of sodium and chloride in serum always declined after water loading; the fall in sodium averaged $6.3 \mathrm{mEq}$. and that in chloride 4.8 $\mathrm{mEq}$. per liter. The decline in serum carbon-dioxide content during the course of the experiments averaged $1.4 \mathrm{mEq}$. per liter. Serum potassium also declined, the mean fall being 0.45 $\mathrm{mEq}$. per liter.
Weight before water loading.

Relative oliguria ascribable to nausea during the first 30 minutes of this period.

\section{B. The influence of dietary salt intake}

Rates of diuresis were very strikingly altered when dietary intake of sodium was raised or lowered (Table I). Subject A, while taking his usual diet, excreted urine at an initial rate of 11.0 ml. per minute with a subsequent decrease to 5.0 ml. per minute. When he took a sodium chloride supplement of $170 \mathrm{mEq}$. on the day prior to study, an average flow of $16.0 \mathrm{ml}$. per minute was maintained for three hours and the rate of diuresis 
never fell below $10.6 \mathrm{ml}$. per minute. A similar relationship to antecedent salt intake was demonstrated in Subjects B, D, E and F. Although in Subject $F$ endogenous creatinine clearance was higher when salt intake was increased, the changes in urine flow were not associated with change in filtration rate in the other subjects. In every instance changes in dietary intake produced the expected increase or decrease in renal excretion of sodium and chloride. Higher rates of urine flow were associated with higher rates of sodium and chloride excretion and lower rates of flow with lower rates of salt excretion.

In each of the five subjects in whom the comparison was made, serum sodium and chloride concentrations were somewhat lower at the lower level of antecedent dietary salt intake, but the values never fell below the normal range. In four of these five subjects hemoglobin and hematocrit levels were lower with the higher salt intake.

\section{The influence of change in posture}

In five experiments the subjects assumed the recumbent posture after the course of the water

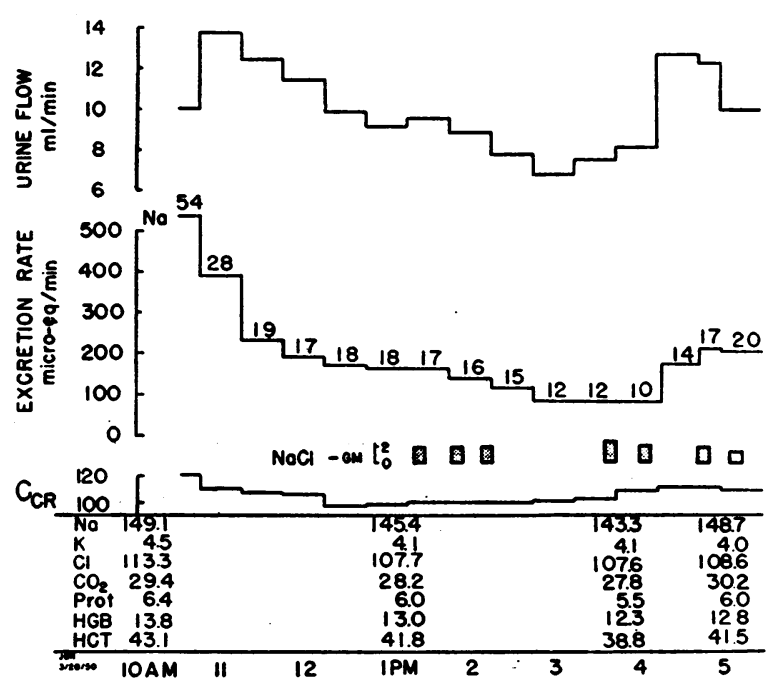

Fig. 1. Decline in Diuresis during Maintained Water Load in Seated Subject and Augmentation after INGestion of Sodium Chloride. Experiment B-3

Water load of $1500 \mathrm{ml}$. established and maintained throughout experiment. Numerals above sodium secretion line refer to urinary sodium concentration (mEq. per liter). Creatinine clearance ( $\mathrm{COR}_{\mathrm{R}}$ ) in $\mathrm{ml}$. per minute. Analytic data for serum electrolytes in lower portion of figure in $\mathrm{mEq}$. per liter; serum protein and hemoglobin in grams per cent; hematocrit in per cent.

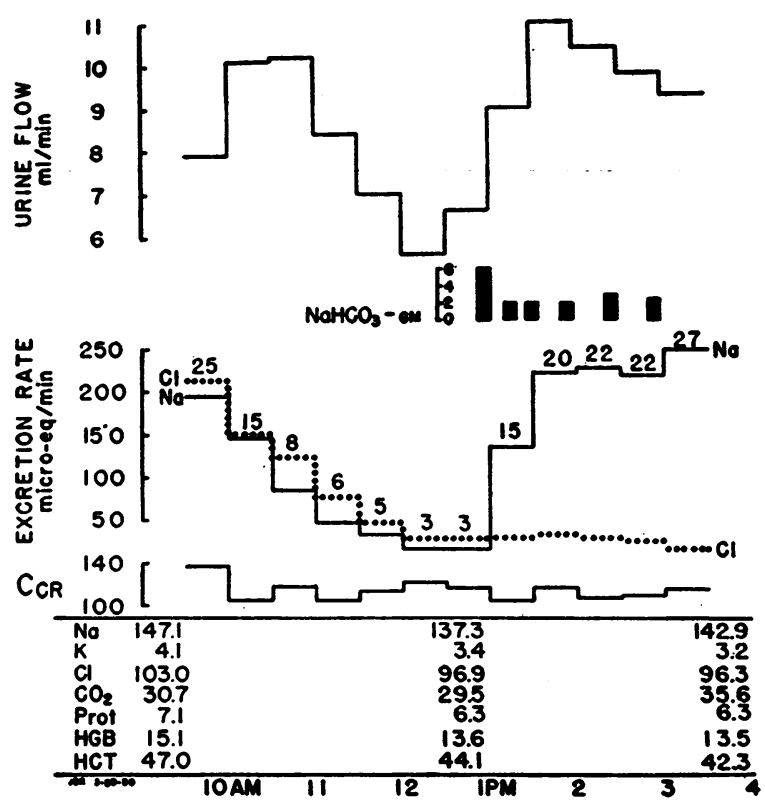

Fig. 2. Decline in Diuresis during Maintained Water Load in Seated Subject and Augmentation after Ingestion of Sodium Bicarbonate. Experiment B-4

Data expressed as in Figure 1.

diuresis had been observed while they sat erect for four to eight hours (Table II). Within 30 to 60 minutes after the subject reclined, increments in urine flow of from 2.2 to $6.0 \mathrm{ml}$. per minute with falling creatinine $U / P$ ratios were observed in four experiments of the group. In the same four experiments an increase in the rate of sodium excretion and in its urinary concentration also took place. Small and probably insignificant increments in endogenous creatinine clearance were observed in three of these four studies. Little change in chloride excretion and no increase in potassium excretion accompanied the augmentation of diuresis. In the one experiment (E-2) in which assumption of the recumbent posture was associated with a further fall in sodium excretion, urine flow continued to decline.

Data pertaining to changes in the composition of blood and serum were obtained in three of the subjects, each of whom manifested during recumbency a further decrease in the level of hemoglobin, hematocrit, and serum total protein suggesting further hemodilution.

\section{The influence of solute loads}

In 12 experiments, after water diuresis had been established and the rate of urine flow was de- 


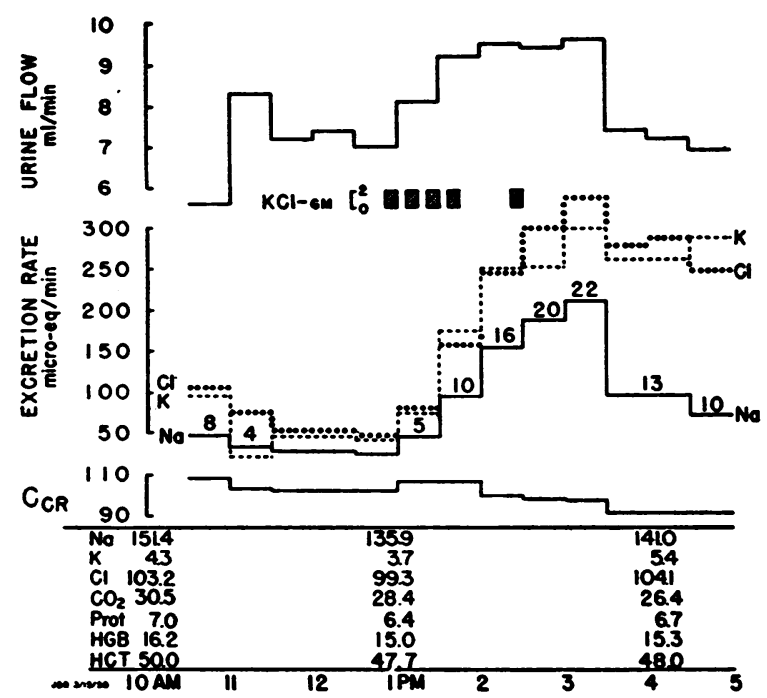

Fig. 3. Augmentation of Diuresis after Ingestion of Potassium Chloride during Maintained Water Load in Seated Subject. Experiment B-5

Data expressed as in Figure 1.

clining, the subject ingested sodium chloride, sodium bicarbonate, potassium chloride, ammonium chloride or urea (Table III, Figures 1-4). In each of these experiments urine flow increased by 2.5 to $5.4 \mathrm{ml}$. per minute after solute administration. $^{3}$ The augmentation of diuresis was regularly associated with an increase in the excretion rate and urinary concentration of sodium, except in one of the four experiments in which urea was taken.

In each of two experiments, following ingestion of sodium bicarbonate, the excretion of potassium rose, while that of chloride fell or remained essentially unchanged. After potassium chloride was given there was a sustained increase in the output of potassium, chloride, water and sodium in one experiment (D-4, Table III). In the other (Figure 3 ) the excretion of water rose while there was concomitant natriuresis; thereafter, sodium excretion, and with it urine flow, again declined despite continued high rates of potassium and chloride excretion. The diuretic response to urea loading, studied in four experiments, was quite variable despite the fact the increments in the excretion of this solute were consistently very

3 The increase in Experiment I-1 was taken as $5.3 \mathrm{ml}$. per minute above the flow of $7.5 \mathrm{ml}$. per minute observed in period III since an acute antidiuretic response, presumably related to abdominal discomfort and nausea, occurred during period IV. large. For example, in experiment I-2, in which sodium excretion was very low, urine flow rose only during the first hour of augmented urea output, whereas in experiment $\mathrm{J}-1$, with much higher rates of sodium excretion, urea loading was followed by a sustained increase in urine flow associated with a marked rise in the excretion rates of sodium and chloride.

No consistent changes incident to solute loading were noted in levels of hemoglobin, hematocrit, or serum total protein concentrations. The expected changes in serum electrolyte concentration were noted after administration of sodium bicarbonate, potassium chloride and ammonium chloride.

\section{DISCUSSION}

Since the early observations of Haldane and Priestley (6), little attention has been paid to variations in renal excretion of water when an excess is maintained in the body, presumably because most investigators have been concerned with the response to the administration of a single large water load. Brun, Knudsen and Raaschou (17) observed that when normal man drank water at a rate of 10 to $20 \mathrm{ml}$. per minute while recumbent

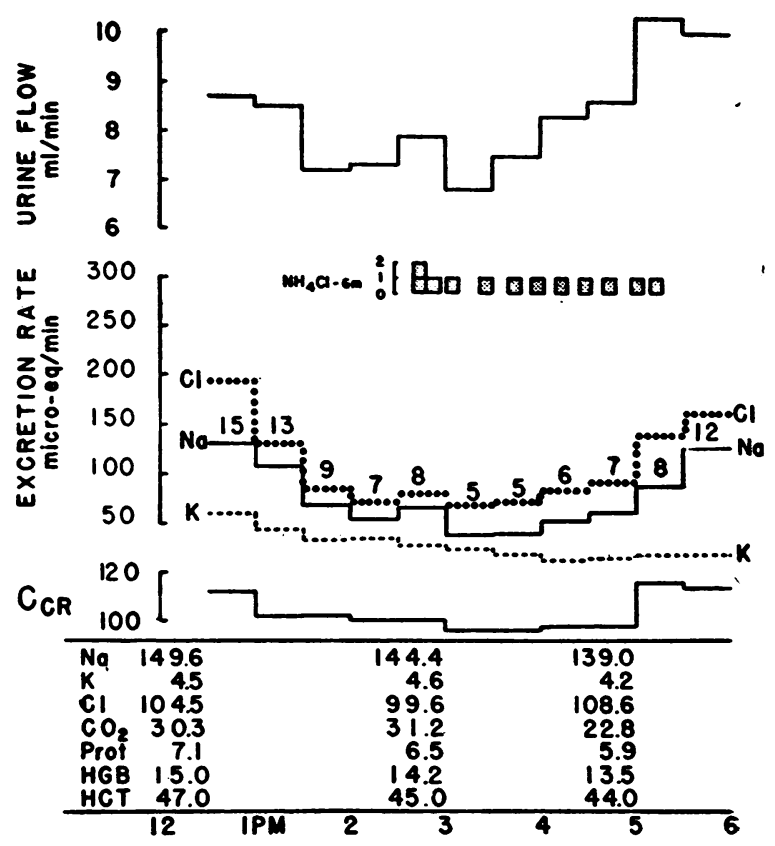

Fig. 4. Augmentation of Diuresis after Ingestion of Ammonium Chloride during Maintained Water Load in Seated Subject. Experiment B-6

Data expressed as in Figure 1. 
the rate of diuresis varied considerably during the first four hours. The data of Baldes and Smirk (10) demonstrate that subjects who have been depleted of sodium exhibit an impaired diuretic response to ingested water, an observation which was confirmed and extended by studies both in man and rabbits by McCance (7-9), who also demonstrated considerable reductions of glomerular filtration rate and urea clearance during salt deficiency. Impaired diuretic responses to ingested water have also been described in dogs and rats depleted of sodium (11), although Cizek and Huang (18) observed normal water diuresis in salt-deficient dogs after an initial period of impaired diuretic response associated with a decreased rate of glomerular filtration. Oliguria may also occur when water intoxication is produced in dogs (19) or rabbits (20).

However, changes in water diuresis under abnormal conditions of salt depletion or water intoxication appear to bear little relation to the variations observed in normal subjects. Changes in urine flow bore no consistent relationship to serum sodium concentration. The clearances and $\mathrm{U} / \mathrm{P}$ ratios of creatinine in the present study indicate that the variations in urine flow observed cannot be related to changes in glomerular filtration rate, but, unless tubular secretion of water is postulated (21), must be determined by alterations in tubular reabsorption of water. Moreover, the data indicate that these changes in tubular reabsorption are associated with alterations in solute excretion and can be most consistently related to the concomitant rate of sodium excretion.

Except in some of the experiments which involved the administration of solute loads, the urinary solutes whose excretion rates varied most widely were sodium and chloride. Hence, urine volume would appear to vary directly with the concomitant rate of sodium excretion even if the rate of flow was actually determined by the total number of osmols of all solutes being excreted, as has been postulated not only under conditions of osmotic diuresis in hydropenic normal subjects (22), but also in patients with diabetes insipidus (23) and in normal subjects whose ADH activity is suppressed by water loading (24). However, the experiments with various solute loads clearly show that the rate of urine flow is not determined by the concomitant rate of total solute excretion, calculated as urea plus twice the sum of sodium, potassium and ammonia. In Experiment I-1 (Table III) urine flow rose from 9.4 to $12.8 \mathrm{ml}$. per minute after ammonium chloride ingestion, while total solute excretion increased from 518 to 775 microosmols per minute with urinary concentrations of 57 and 61 milli-osmols per liter. An entirely different relationship obtained in Experiment I-2, in which urea was the loading solute. Although total solute excretion increased from the pre-loading value of 610 to an average of 1244 micro-osmols per minute in the three periods after urea loading, urine flow increased only during the first of these periods and total osmolar concentration rose from 76 to a maximum of 161 milli-osmols per liter. Similar dissociation of urine flow and total solute excretion is apparent in Experiment $\mathrm{J}-2$ in which urea loading increased total solute excretion to rates greatly in excess of the preloading values without restoring the initial high rates of flow.

The special importance of sodium excretion is apparent in these urea-loading experiments. In Experiment $\mathrm{J}-1$ the rate of sodium excretion, initially 124 to $147 \mathrm{mEq}$. per minute, almost doubled following urea ingestion, and a large sustained increase in urine flow occurred. In experiment $\mathrm{B}-7$, although the initial rate of sodium excretion was lower, a moderate rise took place after urea administration and a sustained rise in urine flow occurred. These experiments may be contrasted with I-2 and J-2 in which sodium excretion remained low and augmentation of urine flow after urea administration was less well maintained.

Augmentation of flow after administration of sodium bicarbonate or ammonium chloride was similarly associated with an increase in the excretion rate of sodium. The association of the excretion of water with that of sodium but not with that of potassium or chloride after administration of potassium chloride was apparent in Experiment B-5 (Figure 3) as well as in a similar study reported previously (25).

It seems clear that the decline in urine flow during maintained water loads, as well as the variations in the magnitude of water diuresis, bears no consistent relationship to the excretion of potassium, chloride, or urea but appears to be most often associated with corresponding variations in the 
rate of sodium excretion. Observations which indicate that a similar relationship obtains in the diurnal variation of the diuretic response to water loading have been reported previously (25) and are consistent with studies described by Stanbury and Thomson (26). Correlation between rates of urine flow and excretion rates of chloride or sodium during water diuresis has also been recognized by Halmágyi (27), Lauson (24) and Ladd (28), as well as by Black and Thomson in subjects maintained on a constant diet with a daily fluid intake of one liter daily (29). It must be emphasized, however, that we have observed large changes in sodium excretion with small changes in water excretion and vice versa. Moreover, in subjects whose sodium intake is very low, initial low rates of urine flow may decline without further decrease in the very low initial rates of sodium excretion. Conversely, recumbent subjects given water loads at night characteristically manifest a steady decline in sodium excretion, without change in the rate of water diuresis (25). Welt and Nelson (30) in five experiments could find "no evident correlation between ... the initial rate of excretion of sodium ... and the height of the maximal diuresis attained." However, in only one of their three subjects is it possible to compare maximal water diuresis at two different levels of sodium excretion. This subject attained a flow of $18.4 \mathrm{ml}$. per minute with a creatinine U/P ratio of 6.5 while excreting 138 $\mu \mathrm{Eq}$. of sodium per minute. On another occasion while excreting sodium at a rate of $216 \mu \mathrm{Eq}$. per minute his maximal flow was $20.1 \mathrm{ml}$. per minute and his creatinine $U / P$ ratio attained the remarkably low value of 4.5 .

The concept of "osmotic diuresis" has been extended by Ladd (28) and by Homer Smith (5, 31 ) to embrace the view that not only under hydropenic conditions but at any given level of $\mathrm{ADH}$ activity the fraction of filtered water excreted by the kidney is determined by the concomitant excretion of solute. It is postulated that in the absence of ADH activity there exists a constant "free water clearance," approximating 13-14 ml. per minute in normal man, which is in turn dependent upon a relatively constant maximal capacity for sodium reabsorption by the distal tubule $\left(\mathrm{Tm}^{\mathrm{d}} \mathrm{Na}\right)$. Urine flows above this basal rate are believed to represent the addition of isotonic proximal tubular fluid, the sodium concentration of which approximates that of glomerular filtrate. This hypothesis requires that urine flow and sodium excretion vary together in a constant and quantitatively predictable manner. In our experiments, although an association between excretion of water and that of sodium is usually apparent, their quantitative relationship is quite variable and therefore calculated "free water clearance" also varies considerably. Such fluctuations in free water clearance imply either that the postulated reabsorptive maximum for sodium undergoes large and rapid alterations, or that facultative tubular water reabsorption is occurring to a variable extent, presumably because the completeness of ADH suppression is variable. If the objections which have been raised by others $(32,33)$ to the existence of a relatively fixed distal tubular maximum for sodium reabsorption are valid, to hypothesize a constant free water clearance when ADH activity is absent or minimal can have little meaning. Our data could then be interpreted to indicate that increased tubular rejection of solutes, particularly sodium, permits increased excretion of water, but that these relationships are too complex or too variable to permit precise quantitative definition.

Alternatively, it may be argued that under the conditions of our experiments small but variable amounts of $\mathrm{ADH}$ activity were present, at least when diuresis decreased, with resultant changes in facultative reabsorption of water. To be sure, the subjects were in a state resembling functional diabetes insipidus, ascribable to inhibition of $\mathrm{ADH}$ secretion by maintained hypotonicity. However, it has been repeatedly demonstrated that the supraoptico-hypophyseal mechanism responds not only to changes in tonicity of the body fluids, but also to other stimuli, including alterations in the volume of extracellular fluid $(14,34-38)$. Except in those experiments during which sodium salts were taken, with continued loss of extracellular electrolyte, some decrease in total ECF volume

4 Although Baldes and Smirk (10) suggested that adaptation to prolonged depression of osmolarity occurs, that such an event did not take place in our experiments is indicated by the failure of additional water loads to increase urine flow once it had diminished. 
can be assumed. ${ }^{5}$ Moreover, redistribution of ECF undoubtedly occurs with pooling of fluid in the legs as the sitting posture is maintained. Movement of extracellular electrolyte into the water introduced into the intestinal tract, first postulated by Priestley (39), would account for a further decrease in interstitial volume. Such a decrease in "effective ECF volume" (40) owing to shrinkage and redistribution of the total ECF might well serve as a stimulus for secretion of some $\mathrm{ADH}$. This stimulus might be especially marked when the ECF volume was initially somewhat low owing to antecedent restriction of dietary salt. Conversely, salt loading or assumption of the recumbent posture should oppose such antidiuretic stimuli. The changes in volume tending to increase or decrease water excretion would be expected to favor parallel changes in the renal excretion of sodium (41). Similar parallelism in the excretion of salt and water has been observed in studies concerning their diurnal variation $(25,26$, 42, 43).

It is possible, therefore, that altered facultative reabsorption of water accounts for some of the changes in urine flow in water-loaded subjects. If the lower rates of diuresis were always dependent upon $\mathrm{ADH}$ secretion, it would be anticipated that at lower rates of flow, urinary concentrations of sodium and chloride would usually increase. Actually, the concentration of salt was characteristically lower at lower rates of urine flow and rose when diuresis was augmented. Nor could an inverse relation between the flow of urine and its total osmolar concentration be demonstrated after urea loading, when osmolarity was calculated either from urinary solutes determined individually or from measurements of freezing point. ${ }^{\circ}$ Moreover, patients and experimental animals with diabetes insipidus exhibit similar variations in urine flow related to the solute load presented for excretion $(21,23,44-49)$.

\footnotetext{
5 Calculation of change in ECF volume from chloride balance and concentrations of chloride in ECF is unsatisfactory since the magnitude of change is too small to be estimated in this manner. Also, as pointed out by Welt and Nelson (30) such an attempt at quantitation is invalidated by the presence of an indeterminate amount of chloride in the unabsorbed water contained within the intestinal lumen.

- The determinations of freezing point depression were generously performed by Dr. Alexander Leaf.
}

The variety of changes observed in the renal excretion of water may thus be related both to alterations in solute load and to slight variations in the level of $\mathrm{ADH}$ activity, dependent upon changes in "effective" ECF volume. Parallel alterations in excretion of water and of sodium would be explained if $a$ ) volume changes which stimulate $\mathrm{ADH}$ excretion also serve as stimuli for sodium retention and $b$ ) tubular water is obligated differently by various solutes and the obligation imposed by sodium is usually more important than that of other solutes, such as urea.

\section{SUMMARY AND CONCLUSIONS}

1. Variations in the diuretic response to ingested water were studied in 10 subjects in whom water loads were established and maintained over periods of four to nine hours.

2. When the subjects remained seated, the rates of urine flow and of sodium excretion characteristically declined during the course of each experiment; when the subjects subsequently reclined, augmentation of urine flow and sodium excretion was observed in four of five experiments.

3. The magnitude of diuresis was increased when the dietary intake of salt was large and decreased when antecedent salt intake had been restricted.

4. The ingestion of sodium chloride, sodium bicarbonate, potassium chloride, ammonium chloride, or urea was associated with an augmentation of urine flow and of solute excretion.

5. The changes in urine flow were related to variations in renal tubular reabsorption of water rather than to glomerular filtration rate.

6. The changes in urine flow were most consistently, although not invariably, related to parallel alterations in excretion of sodium.

7. It is suggested that alterations in the magnitude of water diuresis may be related to changes in sodium excretion because :

a) Despite continued hypotonicity, contraction of effective extracellular volume evokes minimal ADH activity as well as decreased sodium excretion.

b) Tubular water is obligated differently by various solutes and the obligation imposed by sodium is usually more important than that of other solutes. 


\section{ACKNOWLEDGMENT}

The technical assistance of Miss Miriam Halpin, Miss Helen C. Lichwell, and Miss Regina McLean is gratefully acknowledged.

\section{REFERENCES}

1. Rosenbaum, J. D., Nelson, W. P., III, and Strauss, M. B., The dependence of water diuresis upon electrolyte excretion. J. Clin. Invest., 1950, 29, 841.

2. Verney, E. B., Absorption and excretion of water: The antidiuretic hormone. Lancet, 1946, 2, 739, 781.

3. Verney, E. B., Croonian lecture. The antidiuretic hormone and the factors which determine its release. Proc. Roy. Soc. London, 1947, Series B, 135, 25.

4. O'Connor, W. J., The control of urine secretion in mammals by the pars nervosa of the pituitary. Biol. Rev., 1947, 22, 30.

5. Smith, H. W., The Kidney : Structure and Function in Health and Disease. Oxford University Press, New York, 1951.

6. Haldane, J. S., and Priestley, J. G., The regulation of excretion of water by the kidneys. I. J. Physiol., 1916, 50, 296.

7. McCance, R. A., Medical problems in mineral metabolism. III. Experimental human salt deficiency. Lancet, 1936, 1, 823.

8. McCance, R. A., and Widdowson, E. M., The secretion of urine in man during experimental salt deficiency. J. Physiol., 1937, 91, 222.

9. Wilkinson, B. M., and McCance, R. A., The secretion of urine in rabbits during experimental salt deficiency. Quart. J. Exper. Physiol., 1940, 30, 249.

10. Baldes, E. J., and Smirk, F. H., The effect of water drinking, mineral starvation and salt administration on the total osmotic pressure of the blood in man, chiefly in relation to the problems of water absorption and water diuresis. J. Physiol., 1934, $82,62$.

11. Bristol, W. R., Relation of sodium chloride depletion to urine excretion and water intoxication. Am. J. M. Sc., 1951, 221, 412.

12. Meakins, J., and Davies, H. W., Observations on the gases in human arterial and venous blood. $J$. Path. \& Bact., 1920, 23, 451.

13. Adolph, E. F., Physiological Regulations. The Jaques Cattell Press, Lancaster, Pa., 1943, pp. 93-95.

14. Strauss, M. B., Davis, R. K., Rosenbaum, J. D., and Rossmeisl, E. C., "Water diuresis" produced during recumbency by the intravenous infusion of isotonic saline solution. J. Clin. Invest., 1951, 30, 862.

15. Peters, J. H., The determination of creatinine and creatine in blood and urine with the photoelectric colorimeter. J. Biol. Chem., 1942, 146, 179.
16. Hare, R. S., Endogenous creatinine in serum and urine. Proc. Soc. Exper. Biol. \& Med., 1950, 74, 148.

17. Brun, C., Knudsen, E. O. E., and Raaschou, F., The influence of posture on kidney function. I. The fall in the diuresis in the erect posture. Acta med. Scandinav., 1945, 122, 315.

18. Cizek, L. J., and Huang, K. C., Water diuresis in the salt-depleted dog. Am. J. Physiol., 1951, 167, 473.

19. Greene, C. H., and Rowntree, L. G., The effect of the experimental administration of excessive amounts of water. I. On the volume and concentration of the blood. Am. J. Physiol., 1927, 80, 209.

20. Kaplan, B. I., and Smith, H. W., Excretion of inulin, creatinine, xylose and urea in the normal rabbit. Am. J. Physiol., 1935, 113, 354.

21. Brodsky, W. A., and Rapoport, S., The mechanism of polyuria of diabetes insipidus in man. The effect of osmotic loading. J. Clin. Invest., 1951, 30, 282.

22. Rapoport, S., Brodsky, W. A., West, C. D., and Mackler, B., Urinary flow and excretion of solutes during osmotic diuresis in hydropenic man. Am. J. Physiol., 1949, 157, 363.

23. Beaser, S. B., Renal excretory function and diet in diabetes insipidus. Am. J. M. Sc., 1947, 213, 440.

24. Lauson, H. D., The problem of estimating the rate of secretion of antidiuretic hormone in man. Am. J. Med., 1951, 11, 135.

25. Papper, S., and Rosenbaum, J. D., Diurnal variation in the diuretic response to ingested water. J. Clin. Invest., 1952, 31, 401.

26. Stanbury, S. W., and Thomson, A. E., Diurnal variation in electrolyte excretion. Clin. Sc., 1951, 10, 267.

27. Halmágyi, D., The mathematical integration of renal chloride excretion. (Equation of the effect of the postpituitary hormone.) Acta med. Scandinav., 1950, 137, 150.

28. Ladd, M., Renal excretion of sodium and water in man as affected by prehydration, saline infusion, pitressin and thiomerin. J. Applied Physiol., 1952, 4, 602 .

29. Black, D. A. K., and Thomson, A. E., Day-to-day changes in sodium and water output with and without posterior pituitary extract. Clin. Sc., 1951, 10, 511.

30. Welt, L. G., and Nelson, W. P., III, Excretion of water by normal subjects. J. Applied Physiol., 1952, 4, 709.

31. Smith, H. W., Renal excretion of sodium and water. Federation Proc., 1952, 11, 701.

32. Wolf, A. V., The Urinary Function of the Kidney. Grune \& Stratton, Inc., New York, 1950.

33. Tarail, R., Seldin, D. W., and Goodyer, A. V. N., Effects of injection of hypertonic glucose on metabolism of water and electrolytes in patients with edema. J. Clin. Invest., 1951, 30, 1111. 
34. Welt, L. G., and Orloff, J., The effects of an increase in plasma volume on the metabolism and excretion of water and electrolytes by normal subjects. J. Clin. Invest., 1951, 30, 751.

35. Blomhert, G., Over de Zogenaamde Waterdiureese. Thesis. Amsterdam, 1951.

36. Elkinton, J. R., and Squires, R. D., The distribution of body fluids in congestive heart failure. I. Theoretic considerations. Circulation, 1951, 4, 679. 679.

37. Leaf, A., and Mamby, A. R., An antidiuretic mechanism not regulated by extracellular fluid tonicity. J. Clin. Invest., 1952, 31, 60.

38. Blomhert, G., Gerbrandy, J., Molhuysen, J. A., de Vries, L. A., and Borst, J. G. G., Diuretic effect of isotonic saline solution compared with that of water. Influence of diurnal rhythm. Lancet, 1951, 2, 1011.

39. Priestley, J. G., The regulation of excretion of water by the kidneys. II. J. Physiol., 1916, 50, 304.

40. Nelson, W. P., III, Rosenbaum, J. D., and Strauss, M. B., Hyponatremia in hepatic cirrhosis following paracentesis. J. Clin. Invest., 1951, 30, 738.

41. Strauss, M. B., Davis, R. K., Rosenbaum, J. D., and Rossmeisl, E. C., Production of increased renal sodium excretion by the hypotonic expansion of extracellular fluid volume in recumbent subjects. J. Clin. Invest., 1952, 31, 80.
42. Borst, J. G. G., and de Vries, L. A., The three types of "natural" diuresis. Lancet, 1950, $2,1$.

43. Rosenbaum, J. D., Ferguson, B. C., Davis, R. K., and Rossmeisl, E. C., The influence of cortisone upon the diurnal rhythm of renal excretory function. J. Clin. Invest., 1952, 31, 507.

44. Winter, C. A., Sattler, D. C., and Ingram, W. R., The relationship between salt intake and the polyuria of experimental diabetes insipidus. Am. J. Physiol., 1940, 131, 363.

45. Winter, C. A., Ingram, W. R., and Eaton, R. C., Effect of dietary changes upon urine volume and renal function in experimental diabetes insipidus. Am. J. Physiol., 1943, 139, 700.

46. Shannon, J. A., The control of the renal excretion of water. I. The effect of variations in the state of hydration on water excretion in dogs with diabetes insipidus. J. Exper. Med., 1942, 76, 371.

47. Hickey, R. C., and Hare, K., The renal excretion of chloride and water in diabetes insipidus. J. Clin. Invest., 1944, 23, 768.

48. Peters, J. P., The effect of starvation on diabetes insipidus. J.A.M.A., 1944, 126, 1027.

49. Talbot, N. B., Sobel, E. H., McArthur, J. W., and Crawford, J. D., Functional Endocrinology from Birth through Adolescence. Harvard Univ. Press, Cambridge, 1952. 